Edunomics Journal, Vol. 3 (1): page 22-30, Januari 2022

Received: 2021-1-10; Accepted: 2021-1-24

p-ISSN: 2722-6697; e-ISSN: 2723-553X

\title{
Analisis Prosedur Pemberian Kredit Usaha Rakyat Pada BRI Palangka Raya Unit Yos Sudarso
}

\author{
Widayanti ${ }^{1}$, Eko Riadi², Rinto Alexandro ${ }^{3}$, Dehen Erang ${ }^{4}$, Windy Utami Putri ${ }^{5}$ \\ 1* Mahasiswa Program Studi Pendidikan Ekonomi Fakultas Keguruan dan IImu Pendidikan Universitas \\ Palangka Raya \\ 2,3,4,5 Program Studi Pendidikan Ekonomi Fakultas Keguruandan Ilmu Pendidikan Universitas Palangka Raya \\ *Correspondence author: wiwidwidayanti49@gmail.com ;Tel.: +62878428647XX
}

\begin{abstract}
People's Business Credit is one of the government programs that aims to help the Indonesian people who have small businesses to prosper the nation's economy which is carried out by certain banks, one of which is BRI. This study aims to analyze the procedures for granting public private loans as well as the supporting and inhibiting factors for distributing people's business loans at Bank BRI Palangka Raya Unit Yos Sudarso. In this study using qualitative analysis, qualitative analysis techniques are carried out by collecting, compiling and drawing conclusions about the procedure for granting People's Business Credit (KUR) at Bank BRI Palangka Raya unit Yos Sudarso. The techniques of data collection procedures in qualitative analysis are interviews, observation and documentation. Interviews were conducted with the Bank who understands the procedure for granting KUR and one of the customers of the BRI KUR Palangka Raya unit, Yos Sudarso. Based on the results of the research that has been carried out, it shows that the procedure for providing People's Business Credit (KUR) at Bank BRI Palangka Raya unit Yos Sudarso has been carried out quite well and in accordance with government regulations, namely the first stage of credit application, namely the process of collecting administrative data as the first requirement to apply KUR. The second stage is credit analysis, analyzing administrative files and making visits to prospective customers' places of business. The third stage is the credit decision, the head of the unit will provide the final result, namely the credit decision. The fourth stage is credit disbursement, which is filling out a credit agreement or credit agreement regarding the rights and obligations of the customer. The supporting factors for distributing people's business loans are data on business actors who received assistance from the president for MSMEs and data from the market office. The inhibiting factors for the distribution of people's business loans are business actors who do not and do not want to apply for loans and business actors who have businesses but have a bad loan history and some customers who apply for loans but do not own businesses.
\end{abstract}

Keywords: Prosedur Pemberian Kredit Usaha Rakyat, BRI, Masyarakat

\begin{abstract}
Abstrak: Kredit Usaha Rakyat merupakan salahsatu program pemerintah yang bertujuan untuk membantu mas ya rakat Indonesia yang memi liki usaha kecil untuk mensejahterakan perekonomian ba ngsa yang dilakukan oleh bank-bank tertentu salah satunya adalah BRI. Penelitian ini bertujuan untuk menganalisis prosedur pemberian kredit pemerintah s wasta serta faktor pendukung dan penghambat penyaluran kredit usaha rakyat pa da Bank BRI Unit Palangka Raya Yos Sudarso. Dalam penelitian ini menggunakan analisis kualitatif, teknik analisis kualitatif dilakukan dengan mengumpul kan, menyusun dan menarik kesimpulan tentang tata cara pemberian Kredit Usaha Rakyat (KUR) pada Bank BRI unit Palangka Raya Yos Sudarso. Teknik prosedur pengumpulan da ta dalam a nalisis kualitatif adalah wa wancara, observasi dan dokumentasi. Wawancara dilakukan dengan pi hak Bank yang memahami ta ta cara pemberian KUR dan salah satu nasabah KUR BRI unit Palangka Raya, Yos Sudarso. Berdasarkan hasil penelitian yang telah dilakukan menunjukkan bahwa tata cara pemberian Kredit Usaha Rakyat (KUR) pada Bank BRI unit Palangka Raya Yos Sudarso telah dilaksanakan dengan cukup baikdan sesuai dengan peraturan pemerintah yaitu yang pertama tahap pengajuan kredit, yaitu proses pengumpulan data administrasi sebagai syarat a wal pengajuan KUR. Ta hap kedua a dalah a nalisis kredit, analisis berkasa dministrasi da n kunjungan ke tempat usaha calon nasabah. Tahap ketiga adalah keputusan kredit, kepala unit akan memberikan hasil akhir yaitu keputusan kredit. Tahap keempat adalah pen cairan kredit, ya itu mengisi perjanjian kredit a tau credit agreement mengenai hak dan kewajiban nasabah. Faktor pendukung penyaluran kredit usaha rakyat adalah data pelaku usaha yang mendapat bantuan dari presiden untuk UMKM dan data dari kantor pasar. Faktor penghambat penyalurankredit usaha rakyat a dalah pelaku
\end{abstract}


Edunomics Journal, Vol. 3 (1): page 22-30, Januari 2022 Received: 2021-1-10; Accepted: 2021-1-24 p-ISSN: 2722-6697; e-ISSN: 2723-553X

usaha yang ti dak dan tidak ma u mengajukan pinjaman dan pelaku usaha yang memiliki usaha tetapi memiliki riwayat kredit yang buruk dan beberapa nasabah yang mengajukan pinjaman tetapi tidak memiliki usaha.

Kata kunci: Prosedur Pemberian Kredit Usaha Rakyat, BRI, Masyarakat

\section{Pendahuluan}

Peningkatan kualitas hidup masyarakat Indonesia merupakan salah satu tujuan yang hendak dicapai dalam pelaksanaan program pembangunan. Namun untuk memulai meningkatkan kualitas hidup diperlukan salah satunya yaitu modal usaha yang akan mendukung jalannya usaha tersebut. Salah satu lembaga yang dapat meminjamkan atau menambahkan modal ini adalah Bank. Kredit merupakan salah satu bentuk kegiatan penyaluran dana ke masyarakat yang bermanfaat untuk membantu baik orang perorangan maupun badan usaha yang membutuhkan. Bank sebagai salah satu lembaga keuangan haruslah cermat dalam memberikan modal kepada masyarakat yang mengajukan permintaan pinjaman. Hal ini dikarenakan sering kali pemberian modal tersebut tidaklah dapat dilunasi dengan tepat waktu baik pokok pinjaman ataupun bunga yang telah ditetapkan. Kecermatan bagian pihak bank dalam memberikan modal pinjaman tersebut dengan melakukan analisa yang akurat terhadap debitur, akan memperkecil risiko terjadinya kredit macet. Dengan demikian risiko kredit macet tidak akan terjadi bila dalam analisa kredit dilakukan dengan cermat dan akurat. Berdasarkan uraian di atas, penulis tertarik untuk melakukan penelitian dengan judul "Analisis Prosedur Pemberian Kredit Usaha Rakyat Pada Bank BRI Palangka Raya Unit Yos Sudarso."

\section{Metode}

Penelitian ini merupakan penelitian yang menggunakan pendekatan kualitatif. Jenis penelitian yang digunakan dalam penelitian ini adalah penelitian deskriptif. Metode yang digunakan dalam penelitian ini adalah metode deskriptif kualitatif. Pendekatan kualitatif yaitu dilandasi oleh filosofi bahwa peneliti dan sesuatu yang diteliti saling berinteraksi satu sama lain dan tidak saling meniadakan. Atau dengan ungkapan lain bahwa peneliti bergantung pada lingkungan sosialnya. Penelitian ini dilakukan di BRI Palangka Raya Unit Yos Sudarso. Dalam penelitian kualitatif data diperoleh dari hasil observasi, wawancara dan dokumentasi bersama pihak yang bersangkutan dalam penelitian. Adapun sumber data yang digunakan dalam penelitian ini yaitu; data primer adalah data utama yang sangat penting dalam penelitian ini. Merupakan data yang diperoleh secara langsung dengan pihak yang bersangkutan dalam penelitian. Dalam penelitian ini data tersebut diperoleh langsung dari narasumber melalui wawancara kepada staf atau karyawan BRI Palangka Raya unit Yos Sudarso yang menangani bagian KUR atau yang paham dengan prosedur pemberian KUR dan juga dengan salah satu nasabah KUR BRI Yos Sudarso. Yang kedua; data sekunder. Data sekunder dapat diperoleh dari literatur-literatur, buku-buku, internet maupun dari pihak BRI Yos Sudarso itu sendiri. Seperti mengenai sejarah singkat perusahaan, struktur organisasi perusahaan, dan dokumen-dokumen yang berkaitan dengan Kredit Usaha Rakyat.

Dalam melakukan penelitian, terutama dalam penelitian kualitatif, peneliti merupakan instrumen penelitian itu sendiri. Adapun beberapa teknik pengumpulan data dalam penelitian kualitatif adalah sebagai berikut;

1) Observasi

Dalam penelitian ini penulis melakukan observasi dengan mengamati sarana yang terdapat di bank, mengamati sikap pegawai terhadap nasabah, mengamati daya tanggap pegawai dalam melayani nasabah, dan ketentuan dalam Kredit Usaha Rakyat (KUR).

2) Wawancara akan dilakukan dengan staf/karyawan BRI unit Yos Sudarso bagian perkreditan atau yang paham dengan kredit usaha rakyat (KUR) dan juga nasabah KUR BRI Palangka Raya Unit Yos Sudarso.

3) Dokumen atau dokumentasi yang digunakan peneliti sebagai bukti dalam melakukan penelitian yang berwujud atau tertulis. Dokumen dapat berupa berkas-berkas penelitian, catatan-catatan, foto, video, rekaman atau hal-hal dalam bentuk catatan atau elektronik lainnya. 
Analisis yang digunakan dalam penelitian ini adalah analisis kualitatif. Teknik analisis kualitatif dilakukan dengan cara mengumpulkan, menyusun dan menarik kesimpulan mengenai prosedur pemberian Kredit Usaha Rakyat (KUR) pada Bank BRI Palangkaraya unit Yos Sudarso dan faktor pendukung dan pengahambat dalam penyaluran KUR.

\section{Hasil dan Pembahasan}

Kredit Usaha Rakyat (KUR) adalah kredit/pembiayaan modal kerja dan/atau investasi kepada debitur individu/perseorangan, badan usaha dan/atau kelompok usaha yang produktif dan layak namun belum memiliki agunan tambahan atau agunan tambahan belum cukup. UMKM dan Koperasi yang diharapkan dapat mengakses KUR adalah yang bergerak di sektor usaha produktif antara lain: pertanian, perikanan dan kelautan, perindustrian, kehutanan, dan jasa keuangan simpan pinjam. Penyaluran KUR dapat dilakukan langsung, maksudnya UMKM dan Koperasi dapat langsung mengakses KUR di Kantor Cabang atau Kantor Cabang Pembantu Bank Pelaksana. Untuk lebih mendekatkan pelayanan kepada usaha mikro, maka penyaluran KUR dapat juga dilakukan secara tidak langsung, maksudnya usaha mikro dapat mengakses KUR melalui Lembaga Keuangan Mikro dan KSP/USP Koperasi, atau melalui kegiatan linkage program lainnya yang bekerjasama dengan Bank Pelaksana.

Hasil

\section{Pelaksanaan Prosedur Pemberian Kredit Usaha Rakyat (KUR) di BRI Unit Yos Sudarso Palangka Raya}

Berdasarkan hasil penelitian penulis di kantor BRI unit Yos Sudarso Palangka Raya yang dilakukan pada tanggal 26 April 2021 dan hasil wawancara yang dilakukan penulis dengan Mantri Pemasaran Bank BRI Unit Yos Sudarso Palangka Raya, maka penulis dapat mengemukakan bahwa proses penyaluran KUR dilakukan secara bertahap yaitu sebagai berikut:

Gambar 1. Prosedur Pemberian Kredit Usaha Rakyat pada Bank BRI Palangka Raya Unit Yos Sudarso

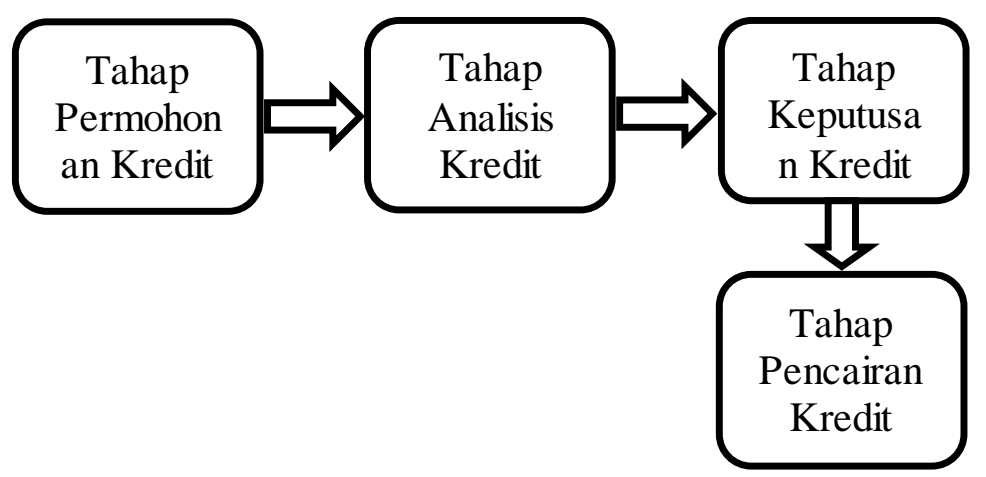

Sumber: BRI Palangka Raya Unit Yos Sudarso

\section{1) Tahap permohonan kredit}

Pertama-tama nasabah atau calon debitur datang ke BRI untuk mengajukan permohonan Kredit Usaha Rakyat (KUR) kepada Customer Service. Kemudian Customer Service akan menanyai dan mendata beberapa informasi tentang calon debitur seperti nama, alamat, jenis usaha dan lama usahanya, serta pengajuan jumlah kredit. Setelah mendata, Customer Service memberikan penjelasan mengenai persyaratan yang harus dilengkapi, angsuran KUR sesuai dengan plafond, jangka waktu, dan bunganya. Setelah itu, Calon debitur kembali lagi ke kantor BRI untuk memenuhi persyaratan yang telah ditetapkan dalam hal pengajuan permohonan Kredit Usaha Rakyat (KUR). Persyaratan umum calon debitur KUR adalah tidak sedang menerima kredit/pembiayaan modal kerja dan atau investasi dari perbankan lain dan atau yang tidak sedang menerima kredit program dari pemerintah. Calon debitur KUR dapat sedang menerima kredit konsumtif (Kredit Kepemilikan Rumah, Kredit Kendaraan Bermotor, Kartu Kredit, dan kredit konsumtif lainnya). Serta yang paling penting usaha telah berjalan minimal 6 bulan berjalan. Adapun syarat-syarat yang harus dipenuhi oleh Calon debitur ialah: 
a. Foto copy KTP (suami istri)

b. Foto copy KK

c. Foto copy jaminan (BPKB, SKT, SHM). (Tidak wajib)

d. Asli surat keterangan usaha dari kelurahan.

Selain calon nasabah datang ke Bank untuk mengajukan KUR, bisa juga calon nasabah mengajukan KUR saat ada pihak Bank sedang melakukan kunjungan ke beberapa tempat seperti pasar atau toko-toko lainnya untuk melakukan penawaran program KUR, yang mungkin beberapa dari calon nasabah malu atau enggan datang ke Bank.

\section{2) Tahap analisis kredit}

Adapun ditahap kedua ini, setelah calon debitur melengkapi persyaratan yang diajukan oleh pihak Bank, maka selanjutnya pihak Bank melakukan pemeriksaan mengenai data yang diberikan oleh Calon debitur apakah data yang diberikan telah sesuai atau tidak dan juga melakukan kunjungan langsung ke tempat usaha Calon debitur untuk memeriksa kebenaran yang ada dilapangan. Surat Keputusan Direksi Bank Indonesia, No. 27/162/KEP/DIR tentang Kewajiban Penyusunan dan Pelaksanaan Kebijaksanaan Perkreditan Bank Bagi Bank Umum. (SK Dir BI No. 27/162/KEP/DIR tanggal 31 Maret 1995) Agar pemberian kredit dapat dilaksanakan secara konsisten dan berdasarkan azas-azas perkreditan yang sehat, maka diperlukan suatu kebijakan perkreditan yang tertulis, yang disetujui oleh dewan komisaris bank dengan sekurang-kurangnya memuat dan mengatur hal-hal pokok sebagai berikut: prinsip kehati-hatian dalam perkreditan; organisasi dan manajemen perkreditan; kebijakan persetujuan kredit; dokumentasi dan administrasi kredit; pengawasan kredit; penyelesaian kredit bermasalah. Dalam hal ini, maka kehati-hatian dalam menganalisis kebenaran data calon debitur sangatlah diperlukan, serta juga harus mendetail dalam setiap pemeriksaan, dari mulai berkas-berkas administrasi, sampai riwayat-riwayat kredit sebelumnya yang dilakukan oleh calon debitur, jika riwayat tersebut bagus, maka kedepannya akan lancar, jika tidak maka akan berpengaruh terhadap putusan pemberian kredit nantinya. Begitu juga dengan keadaan di lapangan, apakah benar usaha tersebut milik calon debitur itu sendiri atau bukan, dan sumber pendapatan calon debitur serta menanyakan kelancaran usaha tersebut dengan tetangga-tetangga, meninjau lokasi tempat usaha itu berada apakah kedepannya kemungkinan akan lancar atau tidak.

\section{3) Tahap putusan permohonan kredit}

Pada tahap ini, kepala unit memeriksa hasil penilaian analisis usaha nasabah yang telah dilakukan oleh CS KUR dan kemudian memberikan putusan mengenai pengajuan pinjaman nasabah. Setelah putusan kredit telah diberikan oleh kepala unit, Pihak BRI unit Yos Sudarso Palangka Raya akan mengkonfirmasi kepada calon debitur bahwa permohonan kreditnya tidak disetujui atau telah disetujui. Putusan disetujuinya sebuah kredit di Bank BRI hanya memakan waktu kurang lebih dua hari jika tak ada gangguan sistem, serja jika berkas-berkas nasabah telah sesuai dan telah dipenuhi dengan baik. Serta setelah penilaian terhadap analisis kelayakan usaha telah dilakukan dan hasil dari analisis tersebut telah sesuai dengan syarat-syarat KUR. Adapun keputusan permohonan kredit dapat berupa dikabulkannya semua permohonan nasabah atau hanya sebagian dari pengajuan permohonan nasabah. Hal tersebut bergantung pada hasil dari penilaian terhadap analisis berkas dan hasil dari peninjauan langsung ke tempat usaha nasabah.

\section{4) Tahap pencairan kredit}

Setelah putusan kredit diberikan, jika disetujui maka calon debitur akan dihubungi untuk datang kembali pada hari yang telah ditentukan oleh pihak bank untuk melakukan akad kredit. Akad kredit berisi hak dan kewajiban nasabah, seperti identitas nasabah, lama usaha, jangka waktu pembayaran yang disesuaikan dengan besarnya pinjaman, angsuran perbulan yang telah ditetapkan pihak Bank melalui plafond KUR, kewajiban nya seperti membayar bunga sebesar $6 \%$ setahun sesuai dengan penetapan dari pemerintah. Jika tak ada lagi gangguan ataupun semua persyaratan telah dipenuhi maka pada tahap ini, pihak bank memberitahukan kepada calon debitur bahwa kredit telah dicairkan dan sudah bisa digunakan oleh nasabah tersebut untuk digunakan sebagaimana mestinya. 


\section{Faktor Pendukung dan Penghambat dalam Penyaluran KUR di BRI Palangka Raya Unit Yos Sudarso}

Dalam proses penyaluran kredit usaha rakyat, dimana kredit usaha rakyat merupakan sebuah program dari pemerintah untuk membantu umkm dan ritel dalam negeri guna meningkatkan ekonomi negara. Maka dari itu pemerintah maupun pihak bank berusaha agar semua umkm di Indonesia dapat terbantu untuk melancarkan atau memajukan usahanya dengan adanya bantuan KUR ini. Baik pemerintah maupun pihak bank bekerja sama agar masalah permodalan maupun perluasan usaha dapat terbantu. Dalam hal ini terdapat beberapa faktor pendukung dalam penyaluran KUR di Bank BRI Palangka Raya unit Yos Sudarso yaitu:

\section{a. Faktor Pendukung}

1. Data penerima bantuan dari presiden untuk warga yang mempunyai usaha.

Adapun daftar masyarkat yang menerima bantuan dari presiden yaitu bantuan langsung tunai (BLT) merupakan masyarakat yang memiliki usaha kecil sehingga pihak bank dapat mengetahui dari data tersebut. Bantuan langsung tunai merupakan salah satu bentuk usaha pemerintah dalam membantu umkm yang terdampak oleh pendemik covid-19. Dengan adanya data tersebut maka pihak bank dapat dengan mudah mengetahui orang-orang yang mempunyai usaha dan yang memerlukan bantuan dana untuk usahanya tersebut, sehingga pihak bank dapat menawarkan KUR tersebut kepada calon debitur jika dana dari bantuan presiden tersebut belum cukup atau masih kurang. Hal ini merupakan salah satu faktor pendorong dalam penyaluran KUR di BRI palangka Raya unit Yos Sudarso.

2. Data dari dinas pasar

Data-data dari dinas pasar mengenai orang-orang yang mempunyai usaha atau yang berjualan di pasar juga merupakan salah satu faktor pendukung dalam penyaluran KUR di BRI palangka Raya Unit Yos Sudarso, dengan begitu pihak bank bisa tau mana orang yang sudah menerima pinjaman KUR maupun yang belum. Bagi yang belum melakukan atau mengajukan pinjaman KUR pihak Bank akan menawarkan kepada para pedagang tersebut. Dengan adanya data tersebut memudahkan pihak bank dalam melakukan penyaluran KUR kepada para pelaku usaha atau pedagang.

\section{b. Faktor Penghambat}

Selain adanya fakor pendukung, ada juga faktor yang menghambat dalam penyaluran KUR di BRI Palangka Raya Unit yos Sudarso yaitu seperti ketika para pelaku usaha yang masih menolak untuk melakukan pinjaman KUR karena masih belum berani apalagi seperti kondisi sekarang (pandemi corona virus). Atau dikarenakan masih banyak kebutuhan lain yang harus ditanggung sehingga membuat para pelaku usaha tidak ingin mengajukan pinjaman KUR agar tidak menjadi kredit bermasalah atau macet dikemudian hari.

Namun pihak bank juga menjelaskan bahwa hal tersebut tidak termasuk sebagai penghambat, karena itu merupakan hak dari nasabah itu sendiri. Karena arti penghambat seperti ada suatu dinding penghalang antara pihak bank dan calon nasabah sehingga tidak bisa menyalurkan KUR dengan lancar. Namun ada beberapa faktor sehingga nasabah tidak dapat diberikan KUR, yaitu:

1. Riwayat pinjaman nasabah yang tidak lancar

Seperti yang telah dibahas sebelumnya bahwa alasan tertolaknya suatu pengajuan KUR yaitu faktor pertama dikarenakan riwayat pinjaman nasabah yang pernah melakukan tunggakan pembayaran atau terdapat pinjaman lain yang yang sedang berjalan namun ada tunggakan, sehingga hal ini menjadi salah satu faktor penghambat dalam penyaluran pemberian KUR. Maka dari itu, nasabah harus dapat membangun kembali kepercayaan kepada pihak bank, dengan cara melunasi terlebih dahulu pinjaman kredit lain yang sedang menunggak agar dapat diterima pengajuan KUR tersebut. Adapun tindakan pihak bank akan 
hal tersebut yaitu salah satunya mengedukasi nasabah dengan cara memberikan penjelasan dan pemahaman mengenai tata cara KUR.

2. Nasabah yang ingin mengajuakan pinjaman KUR namun belum memiliki usaha

Salah satu persyaratan KUR yaitu calon debitur memiliki usaha yang telah berjalan minimal 6 bulan dan memiliki usaha yang layak. Ketika terdapat nasabah yang hendak mengajukan KUR namun belum memiliki usaha, maka hal tersebut dapat langsung ditolak oleh pihak Bank karena tidak dapat memenuhi syarat pemberian KUR.hal ini merupakan salah satu faktor penghambat dalam penyaluran KUR. Dalam hal ini, nasabah tidak punya pilihan lain selain memulai usaha terlebih dahulu selama enam bulan dan kemudian dapat datang kembali ke BRI dengan mengajukan pinjaman KUR. Adapun solusi dari pihak bank dalam hal ini, yaitu memberikan jenis pinjaman lain selain KUR seperti kredit konsumsi, sehingga pihak bank dapat memberikan pinjaman dengan syarat dan ketentuan yang berlaku.

\section{Pembahasan}

Kesimpulan dari hasil penelitian diatas yaitu, dalam hasil wawancara penulis dengan narasumber mengenai prosedur pemberian kredit usaha rakyat pada Bank BRI Palangka Raya Unit Yos Sudarso menurut penulis sudah cukup baik, dimana dalam pelaksanaannya pihak Bank sudah cukup teliti untuk menseleksi calon-calon debitur yang pantas untuk mendapatkan bantuan KUR ini, dengan pertama-tama melihat kelengkapan berkas administrasi calon debitur, dimana salah satu syaratnya ada melampirkan KTP, yang dalam KTP tersebut dapat memberikan informasi mengenai profil calon debitur yaitu tentang riwayat pembayaran kredit yang sebelumnya, latar belakang pendidikannya, keberadaan usahanya, status keluarganya, alamat rumahnya, dan lain-lain. Dengan demikian sesuai dengan prinsip kredit $5 \mathrm{C}$ yaitu salah satunya ada Character untuk mengetahui bagaimana karakter dari calon debitur yang bisa dilihat dari informasi yang ada di KTP seperti pernyataan diatas, dan juga yang di dapat ketika sedang melakukan kunjungan atau on the spot, dimana bisa melihat letak alamat rumah dan usaha calon debitur, apakah ada harapan dan bagimana kondisi sekitar tempat usaha, seperti apakah tempatnya strategis, dan usahanya lancar. Karakter merupakan hal penting dalam penentuan kredit, dimana kredit merupakan tentang kepercayaan, jadi pihak bank harus memiliki kepercayaan terlebih dahulu dengan calon debitur untuk dapat memberikan kredit tersebut. Kepercayaan pula terbentuk dengan adanya bukti atau data. Setelah selesai dengan urusan administrasi dan survey on the spot, maka kepala unit selaku pemberi keputusan kredit akan menilai tentang kelayakan kredit tersebut berdasarkan dokumen dan hasil observasi yang dilakukan pihak Bank, jika semua sudah lengkap dan telah melalui pemeriksaan menyeluruh maka dapat diberikan putusan kredit, jika hasil penilaian menunjukkan baik, maka dapat diberikan kredit, jika terdapat beberapa hal-hal yang tidak memenuhi syarat maka dapat ditinjau ulang ke calon debitur atau dibatalkannya permintaan calon debitur. Putusan kredit yang telah disetujui, dapat langsung dicairkan sehari setelah disetujui. Sebelum dicairkan pihak nasabah juga harus menandatangani akad perjanjian dari pihak Bank, dimana didalamnya terdapat hak dan kewajiban nasabah, dan setelah itu barulah nasabah dapat langsung menggunakan dana tersebut sesuai dengan yang sebagaimana mestinya. Setelah itu, tugas pihak Bank selanjutnya yaitu memonitoring usaha nasabah setelah paling tidak satu bulan pencairan. Pihak Bank datang lagi ketempat nasabah untuk mengetahui perkembangan usaha nasabah, apakah berjalan dengan baik atau tidak, apakah dana tersebut memang sesuai untuk penambahan modal atau digunakan sesuai dengan yang diajukan atau tidak, apakah ada kendala atau tidak. Jika ada kendala, maka akan dituliskan di lembar kunjungan nasabah atau LKN, lalu dicarikan solusinya.

Jika terdapat beberapa kendala atau masalah yang dialami oleh nasabah sehingga nasabah terlambat dalam mengangsur pembayaran kredit, maka pihak bank akan menghubungi atau mendatangi nasabah untuk menanyakan masalah apa yang terjadi agar bisa dicarikan solusi untuk masalah tersebut seperti melakukan restrukturisasi dengan memberikan pilihan yaitu memperpanjang jangka waktu pembayaran dengan angsuran ringan atau perpanjangan jangka waktu pembayaran dengan hanya membayar bunga. Namun jika terjadi kredit macet yang sudah benar-benar tidak tertagih maka hal tersebut dilimpahkan kepada pihak asuransi dikarenakan dalam 
pemberian KUR di Bank BRI unit Yos Sudarso tidak memiliki agunan dari nasabah. Hal ini telah sesuai dengan tujuan pemerintah dalam membantu umkm yaitu KUR adalah program yang dicanangkan oleh pemerintah namun sumber dananya berasal sepenuhnya dari dana bank. Pemerintah memberikan penjaminan terhadap risiko KUR sebesar 70\%, sementara sisanya 30\% ditanggung oleh bank pelaksana. Penjaminan KUR diberikan dalam rangka meningkatkan akses UMKM pada sumber pembiayaan dalam rangka mendorong pertumbuhan ekonomi nasional. Risiko KUR sebesar $70 \%$ dijamin oleh pemerintah melalui PT. Asuransi Kredit Indonesia (Askrindo) dan PT. Sarana Pengembangan Usaha yang telah berganti nama menjadi Perum Jaminan Kredit Indonesia (Jamkrindo). Penyaluran KUR di Bank BRI Palangka Raya Unit Yos Sudarso sampai dengan maret 2021 yaitu sebanyak 437 orang dengan total kurang lebih 9 milyar. Dimana dalam penyaluran tersebut terdapat berbagai macam jenis usaha, dengan jangka waktu pembayaran yang berbeda pula. Dari yang minimal KUR dapat diberikan sebesar 1 juta hingga maksimal 50 juta. Dan untuk kredit bermasalah dalam KUR di BRI Palangka Raya, jumlahnya tidak banyak, namun ada. Dika renakan pada tahun 2020 adanya Covid-19, yang menyebabkan penghasilan para umkm turun. Dan yang paling terdampak yaitu kantin sekolah karena pada saat adanya Covid-19, sekolah diliburkan. Untuk jenis usaha yang lain hampir semua keadaannya sama saja. Dari hasil wawancara dan penjelasan di atas mengenai factor pendukung dan penghambat dalam penyaluran KUR di BRI Palangka raya Unit Yos Sudarso dapat disimpulkan bahwa dalam pelaksanaan KUR di BRI palangka Raya Unit Yos Sudarso tidak terlalu memiliki hambatan yang serius dalam penyaluran tersebut, baik dari internal maupun eksternal. Hal ini menjadi bukti bahwa penyaluran KUR di BRI sekarang ini sudah sangat mudah diakses dan sudah berkembang dengan baik dimana baik dari pihak bank maupun nasabah dapat dengan lancar melaksanakan KUR tanpa adanya suatu hambatan yang serius, dan hampir semua masalah dapat diatasi diatasi dengan mencari titik tengah yang dapat menguntungkan bagi kedua belah pihak yang juga sesuai dengan apa yang ada di prosesdur KUR.

\section{Simpulan}

Berdasarkan pembahasan dan analisis data yang telah dilakukan oleh penulis, maka dapat disimpulkan bahwa:

1. prosedur pemberian Kredit Usaha Rakyat (KUR) pada Bank BRI Palangka Raya Unit Yos Sudarso adalah dimulai dari:

1) tahap permohonan kredit, dimana dalam tahap ini adalah untuk memenuhi berkas admisistrasi.

2) yang kedua adalah tahap analisis kredit, dalam tahap ini pihak bank memeriksa kelengkapan dan keabsahan data administrasi juga on the spot atau survey ke tempat dimana usaha nasabah dijalankan.

3) yang ketiga yaitu tahap putusan permohonan kredit, setelah ditinjau kemudian dinilai apakah nasabah lulus dalam kelengkapan dan keabsahan data-data yang diberikan, jika tidak ada masalah maka keputusan kredit diberikan.

4) dan tahap terakhir yaitu pencairan kredit, setelah putusan kredit diberikan dan disetujui maka akan dilanjutkan dengan pengisian akad kredit dan setelah itu dana akan dicairkan paling cepat dua hari setelah putusan kredit diberikan. Dan dalam tahap-tahap tersebut telah dijalankan dan disesuaikan dengan kebutuhan Bank dalam syarat pemenuhan pemberian KUR.

Dengan demikian, prosedur pemberian kredit usaha rakyat pada BRI Palangka Raya Unit Yos Sudarso telah dilakukan dengan baik dan sesuai dengan peraturan menteri koordinator bidang perekonomian Republik Indonesia yang berlaku.

2. Faktor pendukung dan penghambat dalam penyaluran KUR di BRI palangka Raya unit Yos Sudarso, dalam faktor pendukung penyaluran KUR terdapat dua faktor yang pertama data-data nasabah atau masyarakat yang menerima bantuan langsung tunai dari pemerintah dan yang kedua yaitu data-data dari dinas pasar mengenai jumlah pedagang yang ada di pasar dan berapa dari pedagang tersebut yang sudah pinjam KUR maupun yang belum. 
Sedangkan faktor penghambat dalam penyaluran KUR di BRI Yos Sudarso, yaitu para pedagang yang masih belum ada niat untuk meminjam KUR, atau masih banyak keperluan yang harus ditanggung, dan juga ada beberapa yang ingin meminjam namun tidak memiliki usaha dan juga riwayat pinjaman sebelumnya tidak bagus. Dalam wawancara bersama pihak bank, menyatakan bahwa tidak terlalu memiliki hambatan yang serius dalam proses penyaluran KUR di BRI Yos Sudarso Palangka Raya ini.

\section{DAFTAR RUJUKAN}

Dwi Nugrahaeny 2011, analisis pemberian kredit usaha rakyat pada bank rakyat Indonesia. Diunduh pada tanggal 6 Juli 2021 http://lib.ui.ac.id/file?file=digital/2016-8/20325396-S24722Dwi\%20Nugrahaeny.pdf

Emzir. 2014. Metodologi Penelitian Kualitatif Analisis Data. Jakarta: PT RajaGrafindo Persada. Info BRI. Diunduh pada tanggal 10 Juni 2021. https://bri.co.id/info-perusahaan Kasmir. 2012. Dasar-Dasar Perbankan. Jakarta: PT RajaGrafindo Persada. Kasmir. 2017. Manajemen Perbankan. Jakarta: PT RajaGrafindo Persada.

Kebijakan Perkreditan. Diunduh pada tanggal 29 Mei 2021. https://pdfcoffee.com/surat-keputusandireksi-bank-indonesia-pdf-

free.htm|\#: : :text=(\%20SK\%20Dir\%20BI\%20No.\%2027, suatu\%20kebijakan\%20perkreditan\%20 yang\%20tertulis.\&text=Kebijakan\%20perkreditan\%20bank\%20dimaksud\%20wajib\%20disamp aikan\%20kepada\%20Bank\%20Indonesia.

Landasan Hukum. Diunduh pada tanggal 16 Agustus 2021 http://kur.ekon.go.id/landasan-hukum Mulyati. Etty. 2016. Kredit Perbankan. Bandung: PT Refika Aditama.

Mega Dhaniswara Arifa 2017, analisis prosedur pemberian kredit usaha rakyat (kur) dan sistem pengawasannya oleh PT. Bank Rakyat Indonesia (BRI) unit ciputat pada usaha mikro kecil dan menengah (hlm.98). Diunduh pada tanggal 25 Oktober 2020 http://webcache.googleusercontent.com/search?q=cache:Ec1Qz5tLr4MJ:repository.uinjkt.ac.i d/dspace/bitstream/123456789/35855/1/Mega\%2520Dhaniswara\%2520ArifaFITK+\&cd $=2 \& h l=i d \& c t=c \operatorname{lnk} \& g l=i d$

Muhammad Alhakam 2019, analisis sistem informasi pemberian kredit usaha rakyat (kur) untuk meningkatkan efektivitas pengendalian internal pada pt. Bank rakyat Indonesia (persero) tbk. Unit tarik sidoarjo. Diunduh pada tanggal 6 Juli 2021 http://eprints.ubhara.ac.id/579/1/SKRIPSI\%20JADI\%20CD.pdf

Maksud dan Tujuan KUR. Diunduh pada tanggal 29 Mei 2021 https://kur.ekon.go.id/maksud-dantujuan

Nuning, Indah P. 2017. Penggunaan media video call dalam teknik komunikasi. Jurnal Ilmiah Dinamika Sosial, 1(2): 2581-1224. https://webcache.googleusercontent.com/search?q=cache:WLGBxpDaZwEJ:https://journal.un diknas.ac.id/index.php/fisip/article/download/219/179+\&cd=15\&hl=id\&ct=clnk\&gl=id

Niko 2013, analisis prosedur pemberian kredit usaha rakyat (kur) pada pt. bank rakyat Indonesia (persero) tbk. Unit cinde cabang sriwuaya Palembang (hlm. 58). Diunduh pada tanggal 25 Oktober $2020 \quad$ http://webcache.googleusercontent.com/search?q=cache:5dPCPLr7LQJ:repository.umpalembang.ac.id/id/eprint/1082/1/SKRIPSI8931705244296. $p d f+\& c d=1 \& h l=i d \& c t=c \operatorname{lnk} \& g l=i d$

Sejarah dan Perkembangan Bank BRI. Diunduh pada tanggal 27 Mei 2021. https://www.tagar.id/sejarah-dan-perkembangan-bank-rakyat-indonesia-bri.

Thamrin.A, \& Francis.T. 2014. Bank dan Lembaga Keuangan. Jakarta: PT RajaGrafindo Persada.

Tika Dwi Nur Atin 2018, pengaruh efektivitas kredit usaha rakyat (kur) terhadap peningkatan profit usaha mikro (studi kasus pada nasabah bank rakyat indonesia unit Purwomartani kalasan sleman yogyakarta). Diunduh pada tanggal 6 Juli 2021 http://eprints.uny.ac.id/59647/1/SKRIPSI_TIKA\%20DWI\%20NUR\%20ATIN_14804241018.pdf 
Pedoman Pelaksanaan KUR. Diunduh pada tanggal 16 Agustus 2021 https://covid19.hukumonline.com/wpcontent/uploads/2021/06/peraturan_menteri_koordina tor_bidang_perekonomian_nomor_3 tahun_2021.pdf

Pemberian Kredit Kepada Debitur yang Pernah Macet. Diunduh pada tanggal 25 Oktober 2020. https://www.hukumonline.com/klinik/detail/ulasan/lt4c0d92933c6c6/pemberian-kreditkepada-debitur-yang-pernah-macet-tindak-pidanakah-/

Peraturan KUR. Diunduh pada tanggal 17 Februari 2021. https://www.pdfdrive.com/peraturanprogram-kredit-usaha-rakyat-kur-d198932413.html

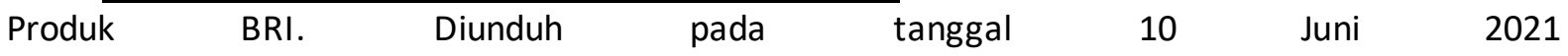

https://www.academia.edu/36349903/Produk_Bank_BRI

Yusuf, Muri. 2016. Metodologi Penelitian. Jakarta: Prenadamedia Group. 